Article

\title{
African Oral Literature and the Humanities: Challenges and Prospects
}

\author{
Enongene Mirabeau Sone
}

Faculty of Humanities, Social Sciences and Law Department of Arts (English), Walter Sisulu University, Nelson Mandela Drive Campus, Mthatha 5117, South Africa; senongene@wsu.ac.za

Received: 16 November 2017; Accepted: 13 March 2018; Published: 22 March 2018

\begin{abstract}
This paper examines the origin, evolution and emergence of folklore (oral literature) as an academic discipline in Africa and its place in the humanities. It draws attention to the richness of indigenous knowledge contained in oral literature and demonstrates how the ethical and moral gap in the existing educational system can be filled by the moral precepts embedded in oral literature. The paper argues that African oral literature has not received the attention it deserves among other disciplines of the humanities in institutions of higher learning in Africa. It concludes that any discussion on African literature will be incomplete, and indeed irrelevant, if it does not equally give adequate attention to the oral literature of the African people. As a result, a new curriculum and pedagogy must be designed to give pride of place to folklore and oral literature as the best repository of our cultural norms and values especially in African tertiary institutions.
\end{abstract}

Keywords: folklore; oral literature; humanities; Africa; education; place; education; universities; curriculum

\section{Introduction}

It would seem that the study of the cultural achievements that make us human should hold pride of place in every educational system of higher education and research. Nations justifiably look to their universities for the education of their citizens and leaders, and for the production of knowledge necessary for growth, security, and prosperity. More often than not, a university's core mission is rooted in the humanities-in the study of culture, history, language, literature, anthropology, philosophy, religion, the arts and folklore. The abovementioned disciplines constitute a people's common heritage. The humanistic disciplines, and particularly folklore, have a clear practical value: they teach critical and analytical thinking while at the same time stimulating the imagination and promoting ethical values. Leaders need these skills to lead, to identify problems, and to conceive creative solutions. Citizens need them to participate actively in public life. Yet the key contribution of the humanities-and folklore in particular-goes beyond cultural education and training in analytical skills. Humanistic studies help ground national dialogue on many urgent issues encompassing humane values. Technical and technological solutions today raise ethical issues and questions that require public understanding and public debate. Humanistic research and teaching illuminate the ethical principles that frame discussion and provide examples of objectivity and fairness in dialogue (ASSAF 2011, p. 25).

In today's landscape of higher education and research in Africa, however, folklore (often considered the mother of the humanities) finds itself in a parlous state. Folklore (oral literature) as a subject has been deprioritized and relegated by policy makers, university officials and even humanities scholars themselves to the bottom of any curriculum. The marginalization of oral literature as an academic discipline in Africa must be remedied, because every knowledge-led development strategy of any nation must have a solid folklore core of humanistic understanding and humane values. The issue with development, especially in Africa, is that many see it from the viewpoint of 
industrialization, or productivity; sometimes at the neglect of the need to transform the human mind. And oral literature is at the center of mind transformation because, like the function of literature itself, it promotes ethically driven actions, by stating what ought to be and not just what is. This is because development begins when the mind is liberated and exposed to a meaningful experience. As Africans, to envision the future, we need to understand the lessons of our past, and to act in the present; we must be sensitive to current cultural complexities enshrined in our folklore. Therefore, reinvigorating the study of oral literature in the university systems in Africa is indispensable to any strategy for development. It would require a concerted, carefully targeted effort by scholars, curriculum designers, policy makers, researchers and university authorities.

This paper examines the origin, evolution and emergence of folklore (oral literature) as an academic discipline in Africa and its place in the humanities. It draws attention to the richness of indigenous knowledge contained in oral literature and demonstrates how the ethical and moral gap in the existing educational system can be filled by the moral precepts embedded in oral literature. The paper argues that African oral literature has not received the attention it deserves among other disciplines of the humanities in institutions of higher learning in Africa. This is because a sound educational policy in any country with folklore at the center enables students to understand their own society before proceeding to learn about other cultures. In other words, a sound grounding of the student in his/her people's culture helps him/her become a useful member of the society.

It should, however, be noted that "there are three categories of literature in Africa, namely oral literature in African languages, written literature in African languages; and written literature in some European languages" (Sone 2009, p. 157). Of these three, oral literature in African languages is naturally the oldest and most predominant in Africa. This is so because its creators and users are, generally speaking, non-literature, rural and agricultural. From the above observation, it follows naturally that an awareness of the African people can only come from the knowledge of the culture, customs and knowledge systems which are vastly found in African oral literature. Thus, oral literature provides the proper milieu for the release of creative energy necessary for the development of a sense of cultural belonging that sustains the foundation of a common identity. It is for this reason that Kimani (as quoted by Ganyi (2016, p. 17)) makes the following statement:

Orality has been an important method of self-understanding, creative relationships and establishing equilibrium between body, soul and environment. Through oral [literature], communities have been able to pass through values, attitudes, knowledge and modes of practice for generations. (Kimani 2010)

Recounting the agelessness of oral literature as folklore in human history, Ganyi (2016, p. 19) also quotes Bynum (1974):

For many millennia, the only instrument of rhythmic words and narrative known in any part of the world was the tongue men were born with [ ... ] so for long ages, so for any way any knowledge could survive from one generation to another was through oral tradition. Rhythmic speech was the world's first great medium of communication for complex ideas and there were certainly media men of astonishing skills long before anyone on earth knew how to write.

It is worthy of mention that prior to the advent of Ruth Finnegan's magnum opus Oral Literature in Africa (1970), it was normal practice and even scholarly in some circles to see oral literature as an appendage of disciplines such as Anthropology, Folkloric Study, History, Cultural Studies, Religious Studies, and even Sociology. Oral literature was never seen as literature, not to mention being studied as literature. Today, as a result of the pioneering works of scholars like Finnegan, Okpewho, Tala, Nketia and many others, oral literature in Africa is becoming a robust and thriving field of study. In its process of evolution, it has encountered prejudice and misinterpretation by many scholars who attempt to coerce it into other non-literary disciplines. 


\section{Conceptualizing Folklore and the Humanities}

The arguments raised in this paper revolve around certain key terms and concepts, namely 'oral literature', 'folklore' and 'the humanities'. I define and situate them within the context in which I use them. I begin with 'oral literature' since it is the main preoccupation in this paper. Early European scholars of oral literature subsumed it under 'folklore' perhaps because folklore encompasses the collective heritage of a rustic people, and also because it lends credence to the Eurocentric view that African culture is still in its primitive stages. Consequently, it may be necessary for me to begin by answering the question, What is folklore? Since there is no consensus as to the meaning of that term, I am of the opinion that three definitions by professional folklorists will provide sufficient cognitive, expressive and socially distinctive features of folklore for the purpose of this paper. Brunvand (1978, pp. 2-3) explains:

Folklore is the traditional, unofficial, non-institutional part of culture. It encompasses all knowledge, understanding, values, attitudes, assumptions, feelings and beliefs transmitted in traditional forms by word of mouth or by customary examples. Many of these habits of thought are common to all human beings, but they always interact with and are influenced by the whole cultural context that surrounds them. Folklore manifests itself in many oral and verbal forms (mentifacts), in kinesiological forms (customary behaviour or social facts) and in material forms (artifacts), but folklore itself is the whole traditional complex of thought, content, and process which ultimately can never be fixed or recorded in its entirety; it lives only in performance or communication as people interact with one another.

Brunvand sees folklore as comprising the unrecorded traditions of people; it includes both form and content of these traditions and their style or technique of communication from person to person. It is a compendium of the genius of a people and, therefore, a living phenomenon. Brunvand reduces the diverse materials and manifestations of folklore into three groups: what people say (verbal folklore), what people do (customary folklore), and what people make (material folklore). What Brunvand designates as "verbal folklore" is what I refer to in this paper as oral literature.

Bascom (1953, p. 283), on his part, emphasizes Brunvand's first category, namely, 'what people say'. That explains why he sees folklore from a narrower perspective as "part of culture, but not the whole of culture. It includes myths, legends, folktales, proverbs, riddles, the texts ballads and other songs." All the terms listed by Bascom, as I demonstrate later, are incorporated under the term 'oral literature'.

Finally, Ben-Amos adopts the general definition of folklore advanced by Brunvand. Like Bascom, his emphasis is on the verbal lore of the people. However, he goes beyond Bascom to comment on the functional aspects of the lore of the people and the social context of performance:

The forms of folklore as speakers delineate and recognize them have cultural and symbolic meanings. Texts, framed into genres and performed in socially defined communicative situations, acquire significances beyond the literal meanings of their constituent words. Ritual songs, for example, which abound with repetitions and obscure terms, are rendered meaningless outside their verbal or social contexts; or in other cases, their transition, from one context to another involves a transformation of meaning. Genealogies and legends function towards the promotion of social stability because they are symbolic expressions of political power and historical truth; parables are effective in settling personal disputes due to their capacity to symbolize moral truth, and talks and riddles can entertain because of their inherent ability to unsettle reality. (Ben-Amos 1974, quoted in (Lindfors 1977, pp. 1-2))

The definition of folklore by Ben-Amos touches on some key features of oral literature. For example, he sees folklore as folk literature which is socially conditioned, secular in intent, and which performs social, political and economic functions. It is this association of oral literature with 
folklore which has led some well-meaning but misdirected literary scholars to refuse to subscribe the status of literature to oral literature. Fortunately, the situation is changing very fast.

Still, I am yet to answer the question, What is oral literature? To answer this question, I first have to answer another question: What is literature? This exercise is necessary because, as I intend to demonstrate, oral literature is literature in its own right albeit with its own specialist terminologies and approaches. Generally, literature is described as a work of art expressed in carefully selected language (spoken or written) which deals with the thoughts, concepts and ideas of an individual or a people. In other words, "it is the creative production of the human mind couched in figurative language. For example, when an individual expresses his joys or sorrows effectively in language, literature is said to be in the making" (Tala 2013, pp. 4-5). Hence, when a literary piece has been composed orally, transmitted orally, performed orally and presented in a special literary language, it is considered to be oral literature. This oral literature is "delivered by word of mouth and aimed at the ear to move the whole body. In place of paper, it relies for propagation and preservation on performance and memory" (Clark 1965, p. 282). Finnegan argues that oral literature "is by definition dependent on a performer who formulates it in words on a specific occasion-there is no other way in which it can be realized as a literary product" (Finnegan 1970, p. 2). In her assessment of the importance of performance in oral verbal arts, Finnegan stresses that "full appreciation must depend on an analysis not only of the verbal interplay and overtones in the piece, its stylistic structure and content, but also of the various detailed devices which the performer has at his disposal to convey his product to the audience" (Finnegan 1970, p. 13).

Oral literature is part of the vast field of knowledge known as 'oral tradition' or 'orality', that is, a system of communication in which information and messages are transmitted verbally from one generation to another. The term 'oral literature' is sometimes used interchangeably with 'folklore' or elements such as language and belief systems that are shared by a group; that which gives a community its cultural and national identity. In contemporary usage 'folklore' means popular and group-oriented expressions of culture. This is the sense in which it is understood in conventions of the United Nations Educational, Scientific and Cultural Organisation (UNESCO). However, Okoh (2012) holds that folklorists are not oral literature practitioners. Though they may have an interest in the same material, and synergize with the oral literature expert in data collection, their strategies and analysis are not the same in the long run. For while the folklorist may have an interest in masquerade dance, marriage, or birth ceremony, the oral literature expert is concerned with literariness. In this paper, the terms 'oral literature' and 'folklore' are used interchangeably to mean the same thing.

African oral literature, therefore, like its written counterpart, has both form and structure which rely on certain principles. As is to be expected, these principles differ from one society to another. In other words, the people who create and use an oral piece are best placed to determine what is literature and what is not in their particular culture because they have been able to develop clear-cut procedure over the years for the performance of oral pieces, which enables these pieces to be classed as oral literature or not. This is to be expected because literature, whether written or oral, is a product and expression of culture. Put differently, oral literature exists both in its composition and appreciation within a specific cultural context.

Since oral literature (folklore) arises from human responses to recurring human situations, it should play a crucial role in the broad disciplines of the humanities and their curricula. There is, therefore, the need to define the humanities. I quote Gardner (1986, p. 9) excellent definition:

The humanities are animated by the urge to understand human beings in all their complexity and contradictions [ ... ] They connect us to our past, linking us to what other human beings have thought and felt and believed and suffered in the process of finding their own humanity. But the humanities not only connect us to our cultural heritage; they also hold out the potential of connecting everything in our experience [ ... ] They offer us the experience of wholeness because they touch us at the deepest levels of mind and personality. They are inclusive disciplines, helping us to create larger and more comprehensive meaning out of 
the fragmentariness of everyday life. It the broadest sense, they are devoted to the task, as one scholar puts it, of 'discovering what it means to be human'.

Gardner's definition points to the fact that the humanities teach people to be human and live with other humans in society. This enables both societies and individuals to promote the idea of the community and to foster in it a sense of belonging and identity. Northrop Frye, one of the world's outstanding scholars of literary criticism, holds that "the humanities are primarily verbal disciplines. At the center are language and literature, the disinterested study of words. Around them is philosophy, the verbal organization of ideas, and history which is essentially the actualization of memory" (Frye 2007, p. 1). He goes further to say that "it is the business of the humanities to nurture the capacity to articulate. Articulateness builds the human community. The surest way to destroy freedom is to destroy the capacity to articulate freely" (Frye 2007, p. 2). The contribution of the humanities to human civilization and cultures is therefore so obvious that no informed person can deny it. A world without the humanities would be inconceivable. Is it possible, for example, to imagine a world without religion, without the fear of God; a world without history, a people without history; a world without the study and use of language and literature; a world without any means of communication or information? Even if it were possible to imagine such a world, it would certainly not be a human world. A world without the humanities would not be a human world, for it is the humanities that humanize the world and make it a human world. Yes, it is the humanities that humanize society and make it a humane society where human values are respected and upheld. The humanities make us humane and promote humane interpersonal relations and peaceful co-existence.

That is why the faculty of humanities has always been among the foundation faculties in the university system, right from the beginning. The earliest universities in Europe, for example the University of Bologna, the University of Naples, the University of Paris, and Oxford University, to name but a few, all began with the faculty of humanities, because the humanities are the prime movers of human civilization and culture. The human in the humanities is what assures our relationship with every field of knowledge. As David Bleich (2002, p. 330) puts it, revising the human factor and the place of literary studies, "literature today with its greater variety and urgency, with its connections to popular culture and music, has become more important to students and society than it was to those who read it only to become more refined". Bleich goes further to show how other sciences operate not necessarily on a human scale but rather with impersonal data that can easily be measured, filed diagnosed, classified or lab-tested. On the other hand, "humanists operate with the uncertainties of thinking, the multiple nature of meaning, the limitations of knowledge, the fragility of rational findings, and, in the end, with what we cannot measure, file, diagnose, classify or test" (Ceia 2013, p. 904). From the above observation, we can say that, at the core of the humanities is the distinctively human capacity to imagine, to interpret and to represent the human experience. The imagination, interpretation and representation of human experiences are the tools humanists use to study most of their subjects.

The role of oral literature as an important discipline in the humanities cannot be overemphasized. In this regard, Wilson (1988, p. 157) avers that no other discipline is more concerned with linking us (humans) to the cultural heritage than folklore; no other discipline is more concerned with the interrelationships of different cultural expressions than is folklore; and no other discipline is more concerned or no other discipline should be more concerned, with discovering what it means to be human. It is this attempt to discover the basis of our common humanity the-imperatives of our human existence- that puts folklore/oral literature study at the very center of humanistic study.

Oral literature teaches, among other things, the tenets of self-restraint, humility, modesty, tolerance, patience, understanding, altruism, and transparency in our dealings with others. Above all, it exhorts us to put our intellectual and technical competence at the service of our society. It may interest the reader to know that thanks to the folklore and literature studies as a whole, I learnt to rely on my own insight and foresight rather than on that of others. I have learnt to come to my own conclusions rather 
than slavishly accept the conclusions of others. Above all, I have learnt to take my own decisions in life for better or for worse and to live with the consequences of my own actions.

Through oral literature, therefore, one can say that Africans take advantage of their ability to dance, sing, chant, narrate and use language in order to show the world how they lived, who they are and what they can do. Reiterating the values of oral literature in Africa, Sone (2009, p. 162) opines that "oral literary forms such as stories, songs and proverbs are metaphors to guide moral choice and self-examination. They are mirrors for seeing things in a particular way. They serve as pedagogic devices [and are] a significant tool for teaching values that guide children's concrete behavior in society." The same goes for all other genres of oral literature which can be relied upon, not only for the edification of society but also for the projection of societal norms, their likes and dislikes, their beliefs and their taboos. It is therefore through these forms of oral literature that emphasize the African world view, environment and knowledge systems that the liberation of Africa from Eurocentric paradigms lies.

\section{Early Misconceptions of African Folklore}

The study of African oral literature by foreign scholars started more than a century ago. Sociologists, ethnologists and anthropologists collected a vast body of oral literature and studied the corpus from the perspectives of their various disciplines. As a result, many of their earlier approaches to the study of oral literature in Africa have been inadequate in the sense that they have obscured certain points of interest and also given birth to several unexamined assumptions about the nature and role of oral literature. For example, Allan Merriam and James Vaughan, both professors of anthropology, declare that "although Africans may have something which is similar in certain aspects to what is known in the West as literature they do not appear to have their own qualitative criteria for evaluating it" (quoted in Tala 1999, p. 7). These two scholars might have turned a blind eye to the fundamental principles of literary appreciation that affirm that literary judgement should rely on knowledge and acceptance of the cultural reference system from which the literature emanates. These scholars, particularly Merriam, are speaking of aesthetic criteria broadly, with no particular reference to Africa but are focusing on music; however, it must be noted that music in the context of this paper is considered as poetry and, therefore, a genre of literature. The observation by the two American scholars referred to above reinforced the idea that Africa was a continent lacking in literary sensibilities. The following quote from Okpewho (1985, pp. 4-5) is instructive:

There used to be a widely held view—especially among European intellectuals who observed African societies in the nineteenth century [ ... ] -that there was nothing of true poetic merit in African oral literature [ ... ] Poetry, these scholars argued, is a mark of an advanced culture or civilization [... ] Traditional African societies were, on the contrary, still groping in the dark and [ ... ] had not yet attained the level of perception where men could engage in the pursuit of poetic excellence; besides, their languages were not yet sufficiently developed to cope with the complex techniques of poetic expression.

Such prejudice against the black man and his culture made juicy reading as Europeans consistently engaged in a repulsive and repugnant stereotyping of the African. The overall intention was to portray black Africans as a people with no contribution to human civilization or the development of a world culture. However, much has been done by Africans. In bringing this point home, Okoh (2012, p. 15) puts forward the following argument:

Educate the renascent African to be a man. Tell him that he had made definite contribution to history. Educate him to appreciate the fact that iron was discovered by Africans, that the conception of God was initiated by Africans, that Africa ruled the world from 765 to 713 B.C., that while Europe slumbered during the 'dark ages', a great civilization flourished on the banks of the Niger, extending from the salt mines of Therghazza in Morocco to lake Tchad. Narrate to him the lore of Ethiopia, of Ghana or Songhay. Let him relish with the world 
that, while Oxford and Cambridge were in their inchoate stages, the University of Sankore, in Timbuctoo, welcomed scholars and learned men from all over the Moslem world, as Sir Percy put it.

The passage provided above emphasizes that African oral literature can offer the younger generation the opportunity to learn much on the contribution of Africans to world civilization. Such knowledge gives meaning to Africanness or blackness and more importantly, challenges, even helps to permanently overthrow, the lingering shackles of European prejudice and presumed supremacy.

I have referred to Western prejudice as a background to understanding two issues. The first concerns why it was easy for Europe to fabricate theories to demonstrate that Africa was the white man's burden or responsibility, the Dark Continent, a land with no history, culture, philosophy or even literature. The second concerns the fact that the field of African oral literature or folklore has been greatly misunderstood, so there is the need to address some of the misconceptions and false claims. To return to the first: because societies in Africa are not generally known to have developed a tradition of writing and could thus be associated with what he calls a "culture of literaturelessness", (Okoh 2012, p. 28) comments as follows:

Like love and laughter, literature (no matter its shape, preferred form, mode of existence or perpetuation) is not the exclusive property of any one nation, culture, or race, no matter how sophisticated, arrogant, or disdainful of other cultures. No society is so backward, deprived, depraved, or under-privileged technologically, as to be totally lacking in literary, artistic activity. God the Creator cannot be said to have denied any people the imagination or capacity to create things-whether literature, or other products-from available raw materials. Such attribute of universality [ ... ] does not preclude the possibility of differences in the manifestations, features or forms of literature from one society to the other. In other words, even within the basic framework called literature, a wide array of differing forms can be detected from different societies.

This observation by Okoh highlights that African oral literature, history, science and philosophy must have existed long before the white man arrived in Africa. These subjects were taught and learned informally and practically when the time was due, when the need arose and when it was pleasurable or advantageous to do so. Sone $(2009$, p. 159) emphasizes that

Africans had an educational philosophy specially adapted to their times, traditions and their philosophy of life. They speculated metaphysically, prescribed and determined the nature of the truth, the good, and the beautiful, and critically analyzed great concepts in order to point out inconsistencies.

Yet when the colonialists arrived, they introduced their own educational system without first trying to know what existed in the African society. They emphasized the universal concept of studies especially in the humanities rather than in the particularized and down-to-earth orientation.

In spite of the aforementioned misconceptions regarding oral literature, it has made significant progress and has thrived amidst a harsh intellectual environment. Much work still remains to be done in the areas of translation, digitalization, collection and preservation. The focus should be on the literariness of the data collected. Tributes are due to scholars such as Finnegan, Scheub, Okpewho, Tala, Gunner, Babalola, Nketia, Anyindoho and many other African scholars whose commitment to oral literature has defined the field and also set it on course, even from the African perspective. Furthermore, the abovementioned scholars also redefined the discourse on oral literature, extricating it from derogatory terms, and helping scholars appreciate it as a full-fledged field of study of its own.

\section{Academic Studies of African Folklore Yesterday and Today}

The impetus for oral literature scholarship developed from renewed interest in European folklore studies in the late 19th century with the publication of works on oral epics of Finland 
and other Scandinavian countries. Interest in field collection and translation grew with the outset of European colonialism in Africa. Okpewho (1992, pp. 3-19) has given details of the various disciplines-anthropology, ethnology, folklore-that influenced the early studies. The American folklorist Richard Dorson (1972) lists some of the early collections of folklore and oral literature in Africa from the 1890s. Many of the European collectors had no interest in the literary value of the oral materials they gathered; they were concerned more with African belief systems and ideological issues contained in them.

The most notable African initiative in oral literary scholarship was taken in 1921 with the founding of the Journal of Bantu Studies jointly published by the University of Cape Town and the University of the Witwatersrand in South Africa. The journal lasted until 1941 and laid the foundation for serious academic assessment of oral literature. At the time, though, the term that was popularly applied was 'native literature' or 'vernacular literature'. In 1938, Bernard Wallet Vilakazi completed an MA thesis at the University of the Witwatersrand with the title 'The conception and development of poetry in Zulu' with reference to izibongo panegyric genre. In 1945, Vilakazi completed his doctoral dissertation titled 'The oral and written literature in Nguni'. In later years, Daniel Kunene completed his MA thesis at the University of Natal. The title was 'An analytical survey of Zulu poetry, both traditional and modern'.

At about the same period that this work was going on in South Africa, oral literature scholarship got fresh impetus from the outcome of research into Homer's epics undertaken by Milman Parry (1971) at the University of California, Berkeley, in the USA and the Sorbonne in France. Homer, the Greek epic story-teller of the 8th century B.C., produced the Iliad and the Odyssey which have enchanted humanity for centuries. The epics were available in translation but apparently no one bothered to inquire into the compositional methods employed. It was assumed that the author was a lettered poet until Parry and his group demonstrated that the epics could only have been produced by an oral artist. The compositional mechanism that Homeric scholars identified is now referred to as 'formula', defined by Albert Bates Lord (1960, p. 15) as "a group of words which is regularly employed under the same metrical conditions to express a given essential idea". After Parry's death, Lord continued the research by testing the theory with epic narratives collected in the former Yugoslavia. The formulaic theory revitalised interest in oral literature all over the world and, by the 1980s, there were about 1800 books and articles from more than 90 language areas based on the formulaic method. There is as yet no direct proof of the impact of formulaic theory on African oral literature but its pervasive influence globally was implicit in the vigorous attention given to African folk poetry and epic narratives.

From the 1930s, the Negritude Movement encouraged enthusiastic collection of African folklore and oral tradition. The leading intellectuals in this effort in the French-speaking countries included Leopold Sedar Senghor and David Diop of Senegal. The Negritude effort dovetailed into the anti-colonial resurgence of the 1940s and this current generated more recordings of materials on oral poetry, epic narratives, and allied genres. The London School of Oriental and African Studies and its counterparts in France, Germany and Belgium supported field research into African traditions. By the 1970s, the Oxford Library of African Literature had published dozens of titles based on African folklore written by both African and Western scholars.

Okpewho (1992, p. 12) observes that a "major advance in the study of African oral literature as literature came when native African scholars began to undertake research into the oral traditions of their own people". Among the pioneers in this new wave were Ghana's J.H.K. Nketia, Djibril T. Niane of Senegal, and Adeboye Babalola of Nigeria. Okpewho ranks Babalola as one of "the first African scholars to revolutionise the study of oral literature", especially in view of his book, The Content and Form of Yoruba Ijala (Babalola 1966). The trend set by Nketia and Babalola in the field of oral poetry was followed in other parts of the continent. Some of the ensuing publications were Trevor Cope's Izibongo: Zulu Praise Poems (Cope 1968), H.F. Morris's The Heroic Recitations of the Bahima of Ankole (Morris 1964) and D.P. Kunene's Heroic Poetry of the Basotho (Kunene 1971). Jeff Opland's book, Xhosa Oral Poetry: An Aspect of a Black South African Tradition (Opland 1983) was an important contribution to the corpus of scholarly works of the period. Other notable titles are Frances Deng's The Dinka and their 
Songs (Deng 1973), and The Horn of my Love by Okot p' Bitek (1974) of Uganda. Ruth Finnegan's Oral Literature in Africa (Finnegan 1970) was perhaps the most ambitious attempt to provide a continental coverage of the varieties of genres at the time.

The situation in Nigeria deserves special attention. The educated elite of the Yoruba of south-western Nigeria were the most active in the study of oral traditions. The progress made by the Yoruba over the century is acknowledged by Alain Ricard (2004, p. 34):

It can be no coincidence that Yoruba oral literature is one of the best known on the continent, that Yoruba researchers are responsible for much of the best work on oral literature and that a Yoruba writer received the first Nobel Prize for literature ever awarded to an African ...

Academic courses on oral literature and folklore were started at the first-generation universities of Ibadan, Lagos, Ife, Nsukka, and Zaria. The institutes of African Studies and centres for the study of languages also offered space for work on indigenous, oral traditions. At the University of Ibadan, the course on the African tradition of oral literature was initiated by the late Oyin Ogunba who completed his PhD thesis titled 'Ritual Drama of the Ijebu People: A Study in Indigenous Festivals' in 1967. Interest in folklore and traditional knowledge was enhanced by the resurgent spirit of nationalism that came with the attainment of independence by Nigeria and many African nations in the 1960s. A similar intellectual ferment was going on in the field of African history. Nigeria's hosting of the Second Festival of the Black and African Arts and Culture (FESTAC) in 1977 was an added incentive.

Okpewho's efforts in the Department of English at the University of Ibadan in the 1970s brought new prospects for oral literature, especially with his commitment to field work and collection by his undergraduate students. Okpewho since established himself as one of the leading scholars of oral literature in Africa and the world. This is evident in the quality of his major books such as The Epic in Africa: Toward a Poetics of Oral Performance (1979), Myth in Africa: A Study of Its Aesthetic and Cultural Relevance (1983), The Oral Performance in Africa (Okpewho 1990, edited), African Oral Literature: Backgrounds, Character and Continuity (Okpewho 1992), Once Upon a Kingdom: Myth, Hegemony, and Identity (1998) and Blood and Tides: The Ozidi Saga and Oral Epic Narratology (Okpewho 2014).

No less epochal was the germinal work of J.P. Clark on The Ozidi Saga (Clark 1977) epic of the Ijo which has had enormous impact on the disciplines of oral literature, theatre and drama. As a meta-genre, The Ozidi Saga embodies all the major resources and media of verbal arts. A great deal of the narration is done in poetic and musical modes.

There was also progress in research into the poetic and musical genres of other groups in Nigeria. In 1971, Romanus Egudu and Donatus Nwoga edited Poetic Heritage: Igbo Traditional Verse (Egudu and Donatus 1971). Wande Abimbola's Ifa Divination Poetry (Abimbola 1977) was published in 1977. Charles Keil's book, Tiv Song (Keil 1979), examined various forms and traditions of song-poetry and musical practice among the Tiv of Benue State. An interesting anthology of essays, Oral Poetry in Nigeria (Abalogu and Amadi-Tsiwala 1981), was edited by Abalogu and Amadi-Tsiwala in 1981. This was the first attempt to provide a broad survey of varieties of poetic genres in different regions of the country. In 1984, Olatunde Olatunji's Features of Yoruba Poetry (Olatunji 1984) brought new insights into an area that had already been well covered.

The situation in the study of African oral literature in East Africa was even more radical than in any other part of the continent. The renewal of interest in African oral literature in East Africa, known as 'The Great Nairobi Literature Debate', was initiated on 24 October 1968 through a departmental memo in the Department of English at the University of Nairobi (Wasamba 2015, p. 19). Scholars like Owuoh Anyumba, Ngugi wa Thiongo, and Taban lo Liyong rebelled against the colonial English syllabus and demanded the introduction of African literature syllabi in schools and universities. In the paper titled 'On the abolition of the English Department', the abovementioned scholars argued that the primary duty of literature is to illuminate the spirit animating a people, to show how it meets the challenges and investigates possible areas of development (Ngugi 1986, p. 89). They emphasised the need for a cultural reinvention and revival of Africa's cultural past to help address some of the 
emerging challenges in independent Kenya. The rebellion led to major changes in the literature syllabi not only at the University of Nairobi in Kenya but also at the University of Dar es Salaam in Tanzania and Makerere University in Uganda, with oral literature receiving serious attention in scholarship. The radical Africanization of the English syllabi at the universities of Makerere and Dar es Salaam was influenced by Pio Zirimu and Grant Kemenju respectively.

As the literary indigenization revolution swept through the three East African universities at the time, it was more pronounced at the University of Nairobi where the name of the department changed from the Department of English to the Department of Literature. This review of the curriculum was based on the argument that "knowing oneself and one's environment was the correct basis of absorbing the world" (Ngugi 1993, p. 9). The new curriculum placed East African literature and folklore in the first year, with other 'Third World' and then European literatures introduced in the following two years. The shift from 'English' to 'Literature' had nationalistic ramifications. Making national literatures core curriculum helped redefine the nation (Sicherman 1998, p. 129).

However, the Africanization of Literature syllabi in the East African region did not achieve much initially. According to Wasamba (2014, p. 7), "the change became famous due to its nationalistic and political import [rather] than academic achievements. It created a weak foundation in terms of researching, teaching, examination and criticism of oral literature." Wasamba further says that though local scholars were urgently keen to re-introduce oral literature into the educational system, they did not ask, which education? They eventually bent African oral literature to meet the requirements of Written European Literature. As a result, they focused more on writing for examination purposes as an alternative to preserving the texts in performances. Instead of inviting resident artists to be employed in departments of Literature, History, and African Studies to deliver the texts as was the norm in the community, academics occasionally took their students to the field to listen to the performances; not to enjoy and learn from them, but to have an ear for transcription, translation and analysis to earn high grades (Wasamba 2014, p. 7). Despite the failures and the imperfections of the system, the experiences referred to above reflect the attachment Kenyans have for their oral literature as a means of liberating their society from colonial domination and repositioning them for democratic developments. This explains why Wafula (2012, p. 490) posits that "one of Kenya's basic educational objectives, according to the Kenyan National Examinations Council regulations and syllabus (1993), states that a sound educational policy is one that enables students to understand the culture and environment of their own society before proceeding to learn about other cultures". A sound grounding of the student in his/her people's culture helps him/her to become a useful member of the society.

Another important development in the growth of oral literature in Kenya is the contribution of Owuoh Anyumba (Wasamba 2015, p. 24). As mentioned earlier, he was one among eminent scholars that championed the shift from English literature to literature in English in East Africa. As a scholar of oral literature at the University of Nairobi, he made a contribution in laying the foundation for systematic oral literature field work in Kenya and the East African region as a whole. Operating with zeal in the $60 \mathrm{~s}, 70 \mathrm{~s}$ and $80 \mathrm{~s}$, Anyumba recorded several performances based on the structuralist school. Most of the recordings were done with students of the University of Nairobi under his training while he did the rest alone.

From 2000, scholarship in oral literature in Kenya was revived through the activities of the Kenya Oral Literature Association (KOLA). KOLA is a professional organization of ethnographers with a passion for research in oral genres in Kenya. It is a multi-disciplinary forum for historians, anthropologists, philosophers, linguists, sociologists and economists. There is equal interest in theoretical, technological and methodological issues. The association has engaged public and private universities, cultural institutes, museums, archives, the donor community and individual researchers to shape the strategic direction for cultural studies in Kenya. One area that the association focuses on currently is digitalization of intangible heritage and how best to secure the gains of the digital revolution without falling into the trap of Western and Eastern commercial avarice. 
In southern Africa, most of the pioneering works on oral literature occurred within the context of colonization. For example, missionaries sought to understand their prospective converts as well as the languages they spoke. Governors and magistrates wanted to find better ways to govern the people and this led to their interest in folklore. As a result, the collection and documentation of southern African oral literature during the colonial/apartheid period was done mostly from the perspective of colonial administration. In the collection of oral material, it is evident that not all aspects of oral literature were represented because of the collection, the collectors themselves or the manner of the collections (Sone 2008, p. 82). This was also because of the editorial requirements of the colonizers. Other collectors were more interested in translating and 'modernizing' the stories for Western consumption (Eliot 1951). A large number of collectors saw African narratives as the answer to literacy problems of black people (Cock 1931). However, there have been significant and ground-breaking studies of oral literature by black scholars, in particular H.I.E. Dhlomo (Dhlomo [1939] 1993; Dhlomo [1947-1948] 1977), B.W. Vilakazi (Vilakazi [1938] 1993, 1945), A.C. Jordan (1973), D.P. Kunene (1971) and Mazisi Kunene (1961) which continue to inform oral literature studies in South Africa. According to Brown (2016, pp. 108-9), with the 'retribalizing' policy of the National Party that came to power in 1948 in South Africa, "studies in oral literature-especially in departments of African languages-became, in some cases, problematically entangled with the ideology of apartheid and its promotion of fossilized notions of 'ethnic identity' and 'racial otherness'".

In post-apartheid South Africa, oral literature is still struggling to be recognized as an independent discipline. It is not a stand-alone program because it is still an appendage within African languages departments. The English departments focused on 'orature', as they called it, and historians, library scientists and anthropologists worked on oral tradition. According to a study conducted by Makgopa (2016), "out of the 26 Higher Education Institutions in South Africa, 14 offer oral literature. MAs and PhDs are offered pending on the nature of the study conducted." Makgopa also points out that only the University of Limpopo attempted to come up with a postgraduate qualification in oral literature. This proposal encountered several problems and died a natural death due to internal problems. Also, the then University of Natal (now KwaZulu-Natal) established the Oral Documentation Centre.

Despite the challenges articulated above, much has been written and published on oral literature in post-apartheid South Africa. Prominent authors include Leroy Vail and Landeg White (Vail and White 1991), Isabel Hofmeyer (1993), Duncan Brown (1998, 1999, 2006, 2014), Russell Kaschula (1993, 2001, 2002), Liz Gunner (1994), Harold Scheub (1996) and Jeff Opland (1998). It is evident therefore, that there has been adequate awareness and participation by both foreign and Southern African scholars in the study of oral literature and that the future of the discipline is bright. The Southern African Folklore Society (SAFOS) was created and takes credit for some of these developments. It is worth mentioning that after the creation of SAFOS, Thosago was the first among SAFOS associates through his 1999 article, '(Un)changing theoretical trends in the study of folklore in South Africa', to raise issues regarding the stagnation of folklore studies in South Africa (Thosago 1999). The subsequent article, 'Teaching an eccentric subject? Why folklore studies is, almost, a non-existent discipline in South Africa' by Mashige and Thosago (2005), still highlights issues contained in the earlier article.

\section{Folklore and Educational Systems in Africa}

Generally speaking, education is the process of establishing habits of critical thinking, intellectual development and independent appraisal of human values and qualities. Fonlon (2010, p. 15) defines education as "the physical, the aesthetic, the intellectual and the moral upbringing of man". Seen from this perspective, education is meant to develop the individual intellectually and morally and prepare him/her to function effectively in society. Fonlon further states that if education is to perform its fundamental function of nurturing the individual it must, of necessity, have a system. Fonlon (2010, p. 14) argues that the nature of this system of education 
will depend, in the main on what sort of individual that particular society wants to produce, on what is their idea of the perfect man. And their idea of the perfect man will depend, to a large extent, on the problems that beset the society; for their ideal man will be the man best equipped, best able to meet these problems.

Thus, Fonlon says that an educational system is established by a particular society to meet its specific needs. Agbase (quoted in Tala 2012, p. 19) reinforces Fonlon's point:

No educational system stands apart from the society which establishes it. It has purpose that must be achieved if that society is to continue in the right direction. Education is meant to be embedded in that society, drawing inspiration and nourishment from it, and in turn contributing to societal opportunities for growth and renewal.

Agbase's statement above raises the following questions: From where did the educational system of most African countries originate? What is the philosophy behind it? What are its guidelines? By whom is it managed? What and whose social vision is it setting out to serve? The obvious answers to these questions are that the educational systems of most African countries originated from imperialist Europe. These systems were managed in the first instance by the Europeans themselves and later by their African surrogates for the purposes of imperialist domination and cultural oppression. That explains, in part, why the educational system in Africa today concentrates on imparting cognitive, linguistic and vocational skills that transform young machines into efficient machines designed exclusively for the labor market. At the same time, it ignores the teaching of indigenous knowledge and humanistic values contained in African oral literature that help in the creation of socially responsible individuals; hence, the serious incongruities that exist between what is being taught in our schools, colleges, and universities today and what is socially and politically relevant. This is regretful because oral literature has been used in the past and is still being used, among other things, to teach the importance of togetherness and group solidarity; to inculcate the necessity for mutual respect, tolerance and moderation; to reiterate the need for appropriate action; to ensure compliance with religious norms; to remind the people of the necessity of circumspection, and the importance of recognizing and accepting one's limitations. As an example of "the richness of indigenous knowledge contained in oral literature", the film Keïta, Heritage of the Griot, by Dani Kouyaté (1996) (father Sotigui Kouyaté plays the role of the 'djeli 'griot' in the film and they are from a griot family). This film treats the theme of the importance of knowing one's own cultural heritage, with specific reference to the Sunjata epic and applies wisdom of particular proverbs to specific issues and circumstances. Also, various aspects of oral literature have been used in different parts of Africa to achieve national goals. A long and dark history of foreign domination in Kenya gave rise to stiff resistance on the part of the natives, unprecedented in the African continent. The Kenyans formed nationalist organizations to pressure for reforms through petitions, marches and demonstrations. Faced with ruthless separation and bans some of these movements regrouped themselves in the hinterlands and bushes to wage one of the fiercest liberation wars Africa has ever known. These militant groups of workers came to be known as the Mau Mau. What accounted for the people's victory? Not their military arsenal, of course, for the colonialists were better armed in this regard. Their victory, surprisingly, was a result of the fact they identified and developed those aspects of their indigenous knowledge and oral literature which strengthened their identity and resistance. Alembong (1996, p. 121) points out that "[s]ongs of struggle, songs of praise, songs of hope, for example, were common features of their daily lives". At last, the colonialists gave in and so, on 12 December 1963, Kenya gained its political independence.

Similarly, Okpewho (1985, p. 258) notes that the song titled "Toro gidi uzvtonge" in the original Shona version was one of many used by the members of Zimbabwe African National Liberation Army (ZANLA) for enlisting recruits inside the then Rhodesia against forced white rule. It is worth noting that the title of the song "Toro gidi uzvtonge" is loosely translated as "Take up arms and liberate yourselves" reveals a sense of history and national commitment. 
The Kenyan and Zimbabwean examples of a reliance on one's indigenous knowledge and oral literature for inspiration and national ideals underscore the fact that one must be firmly anchored to one's roots while looking out to the external world.

As the distinguished former Secretary General of the United Nations Organization, Kofi Anan (quoted in Tala 2013, p. 69) affirms:

We have African traditions to draw on, traditions that teach us the values of democracy based on consensus. Our traditions teach us to respect each other; to share power; to give every man his say and every woman hers. Consent and consensus achieved through long and patient discussion are at the heart of these traditions.

Anan makes the point that before the advent of colonialism, Africans had a viable traditional system of education. It was informal: the young learnt through watching and imitating the examples of grown-ups and by participating in the daily life of the community. The good counsel contained in the extract quoted above provides a good enough reason why Africans should take their indigenous knowledge contained in their oral literature seriously. Ours is an age in which societal values are flouted with impunity and so, revival of, and a tapping from our oral traditions will help in the fostering of, and the tapping of social propriety. African folktales, legends and myths, for instance, teach us virtues such as love, kindness, obedience, fidelity, gratitude, hard work, heroism, and spiritual sanity. While the characters in these narrative forms who promote these values are rewarded, those whose actions or behavior amount to their negation are mercilessly punished. These oral literature forms, therefore, are used for social regulation and control. Does good judgement not demand, then, that we should use these forms of oral literature in the education of our children, and even for our edification? And when properly schooled in our oral tradition, when properly edified by their teachings, does it not follow then that these traditions shall remain the bedrock on which we can raise the foundation of our identity? Therefore, this oral literature is neither antiquarian nor antediluvian. Rather, it remains ever changing and dynamic. Its thematic content is being constantly broadened to reflect the important issues of the day. Above all, it maintains, as Bukenya et al. (1994, p. 2) assert, its educational relevance:

We undertake it mainly because we are convinced that it is a valuable educational experience contributing to the total growth, development and self-fulfillment of the person exposed to it. Oral literature imparts to the growing person useful cognitive and affective skills which enable the person to live a rewarding life and to be a useful member of society. Oral literature should make the learner more keenly observant, more sensibly and sensitively responsive towards her or his own self, fellow human beings and the environment. Above all, oral literature being a mode of communication should make the learner a competent, more skillful and more concerned communicator, especially through the oral mode.

Dona Rosenberg (quoted in Tala 2013, p. 74) is concerned with the moral capacity of oral literature to help members of a community to make sense out of the many imponderables of life and to create order out of chaos by providing moral answers to philosophical questions such as:

Who am I? What is the nature of the universe in which I live? How much do I relate to both the known and the unknown world? How much control do I have over my own life? What must I do to survive? How can I balance my own desires with my responsibilities to my family, my community, and the powers that control my world? How can I reconcile myself to the inevitability of death?

Hence, by deliberately hesitating or even refusing to incorporate oral literature fully into the educational system, African governments are indirectly pushing their citizens to commit cultural suicide.

It is obvious from the above that the fundamental problem facing educationists in Africa is the rapid and significant decline in the ethological aspects of the education offered in the continent since the 
attainment of political independence. The point must, however, be made that the educational systems in many African countries have been subjected to a plethora of transformations, transmutations, transmogrifications and reformations over the years, all in the crucial attempt to decolonize the system so that it can respond effectively to the realities and exigencies of contemporary Africa. But, the efforts of the many governments to revamp the system, though laudable and commendable, have been grossly inadequate. The over-riding question therefore is: How can our policy makers supplement the obvious ethical deficiencies in the present educational systems? There are several answers to this perplexing question. But, for the purposes of this paper, I limit myself to three. Fonlon believes very strongly in religion as the basis of moral education. This is what he has to say: "I believe in God, as the fount and origin, the final end, the Alpha and Omega, of all Truth and Goodness and Sublimeness. I believe that no right-minded makers of universities should ignore (not to speak of spurn) that science which strives to make man's knowledge of Him more profound; they will be omitting the vital link, in the chain of college knowledge" (Fonlon 2010, p. 13).

Anomah-Ngu (quoted in Tala 2012, p. 22) comments as follows:

Although technical competence is on the increase in the world, it is my personal opinion that the decline in the quality of University men and women as leaders in many parts of the world especially in Africa is due, to a great extent, to the exclusion of religion from the University. This exclusion gives the impression that man has himself become a simple piece, an object without a soul. Since machines can do no wrong as they have no soul, man has to equate his own actions with those of the machines. Morality is based ultimately on the conscious awareness of right and wrong, which in themselves are anchored ultimately on the knowledge of, and acknowledgement of the supremacy of God. The absence of religion which teaches and reinforces this morality must inevitably lead to chaos and anarchy.

Both Fonlon and Anomah-Ngu are right in saying that religion and morality are two sides of the same coin and that religion should be fully integrated into our educational system. I agree with them that the fear of the Lord is the beginning of wisdom. I also agree with them that morality and a unified cultural ethos cannot be achieved or sustained in any institution of learning in the absence of religion. The only difference between us is one of degree rather than of substance. That is, while Fonlon and Anomah-Ngu see morality from the perspective of the Christian religion, I as an Africanist, see the same phenomenon from the perspective of our oral literature which contains our indigenous knowledge, and which is anchored in our traditional religion. I therefore believe that since the educational system was not originally designed specifically for Africans, it follows, logically, that there is an urgent need to re-orientate and relate it to the rehabilitation of Africa's culture, tradition and value system. That is why I wholeheartedly endorse the view advanced by Olowo Ojoade that the "quality of instruction at all levels has to be oriented towards inculcating the following: moral and spiritual values in inter-personal and human relations" (quoted in Ongoum and Tcheho 1989, p. 101). He adds that this instruction must be geared towards "self-realization, better human relationships, the right types of values and attitudes for the survival of the individual and the society" (Ongoum and Tcheho 1989, p. 101). This return to a full understanding of traditional principles and a full grasp of how they can work especially in changing times and circumstances is what Africans really need if they are to break away from the cultural limbo that is destroying the social health of their continent.

Therefore, what is imperative today is that Africans both old and young must make a conscious effort to re-familiarize themselves with, and re-assimilate their cultural values. For that to become a reality, our educational policy makers must follow the advice of Oyekan Owomoyela (1989, p. 414) and ensure that oral literature reassumes the educational and ethical roles it played in the traditional context:

The goal of policy makers must therefore be to ensure that a thorough grounding in the ways of our fathers is a mandatory and significant part of the upbringing of youth, and this can be done by making folklore in all its ramifications a central part of the educational curriculum, 
and a mandatory subject for all. By so doing we might in time achieve, once again, societies in which the observance of proper form translates into stability, harmony, and collective ease.

From the above observations, since education underlies the struggle of all communities to assert themselves and gain control over their lives in the present world, the question that many concerned African scholars are bound to ask is, Whose or which education does the African child acquire, African or Western? Education in indigenous African knowledge systems is certainly not what the African child acquires and Western education only succeeds in turning him/her into a misfit in his/her African environment. The child develops a dual personality and ends up in confusion and mental as well as social retardation. Hicks (2004, p. 14) posits that "education must take into cognizance the socio-cultural environment of the recipient of the education in order that he/she does not become a misfit in society". The present mode of education in Africa is formal and literacy oriented and Western formal education emphasizes teaching that fits out the individual for competition and survival in a modern capitalist market economy which is the basis of the concept of globalization. Africa cannot continue to depend on others to liberate them. They need to take deliberate steps to liberate themselves, and the tool for liberation is first and foremost their indigenous knowledge—knowledge of self, group, environment, ancestry, nature, society and the world beyond.

\section{The Situation Today and Its Challenges}

However, African oral literature is beginning to occupy an important place in the educational programs of many African universities today because after the attainment of political independence by most African countries, their governments gradually became aware that African cultures, for the most part, still exist in the oral tradition and that Africans continue to transmit their cultures through oral expression. It was also realized that very little has been done in the way of systematic collection and presentation of African cultural heritage. Furthermore, the acceptance of governments of most independent African countries of the responsibility to ensure that the cultural heritage of their people is properly recorded coincided with the renewed interests of scholars in Africa and African diaspora. Ikiddeh (1987) confirms the above observation by saying that since oral literature was not part of the academic tradition of the West, it had little chance in the first place of being on the educational curriculum of colonial institutions. But when the educational policy-making process passed into the hands of the natives, things took a different shape and they have continued to improve ever since. The place of oral literature in the curriculum today has changed. Oral literature is now taught in many African universities and as Ighile (2013, p. 7) points out, "it is fast becoming one of the most popular disciplines in the humanities".

Despite the fact that oral literature has been taught as an academic discipline in the various African universities since the late 1960s, and early 1980s in secondary schools, the teaching of oral literature in secondary schools is beset with many problems. The general feeling is that the teaching is rather haphazard. The integration of English language and literature has further compounded the problem, making some teachers de-emphasize oral literature.

Another problem besetting the study of oral literature on the African continent is that the educational syllabuses on literature in most African countries do not emphasize oral literature. Hence, after more than five decades of political independence, hardly any African country can boast of a well-articulated syllabus on the oral literature of its people. Furthermore, the recent increase in interest in oral literature in Africa has not encouraged the production of appropriate texts designed to provide the reader with the essential tools for appreciating the oral literature.

The university system in many African countries has a share of the blame for the state of the art in oral literature. For while students in many African universities graduate with a degree in English, German and French, very few or none may graduate with an interest in the oral literature of their own people. Okoh (2012) sees this as "a disservice from our universities". One reason for this situation is the misconception (and sheer arrogance) of many a scholar who should know better. Such situations deny oral literature its interdisciplinary synergy with other fields of research. 
The effects of globalization on African oral literature have been discussed at length by Sone (2011) in a paper titled 'Swazi oral literature studies yesterday and today: The way forward'. However, it is useful to mention it here briefly. 'Globalization' is a term that is applied mostly in economic and political studies, but, for the purpose of this paper, it can be seen as the process of trying to replace African culture and values with the values of technologically advanced countries. It can also mean the movement of Africans of the multiplicity of their ethnic languages and cultures into a global culture which, in effect, implies a common global language and a common global literature. In other words, globalization is a concept that implies one world which is economically (and culturally) controlled by a group of nations (notably Western). Communication as a key human factor plays a very important role in globalization. Information devices such as cellular mobile phones, emails, fax and the World Wide Web have reduced the world into a global village. However, as Colman (1971, quoted by Sone (2011, p. 46)) observes, "the effect of technological advancement and Western incursion into Africa has profoundly affected the oral traditions, traditional loyalties, patterns of behavior, and social obligation and created new tension and economic insecurity as well as individualistic and materialistic attitudes and values". Globalization, therefore, gives the impression the whole world is turning towards a homogenous culture and Western culture is presented as the standard by which all cultures are measured.

The forces of globalization are such that individual African cultures are unable to resist them, for as Wilfred (1997, p. 42) says, "[A]ny culture that fails to get integrated into this process of globalization is left behind, suffers in isolation and stays in its primitivism." Getting integrated as a Third World continent is not easy, so Africans are becoming excluded from having control over factors affecting their livelihood and their place in the 'global village'. They are, to use Wolf $(1995$, p. 80) words, being "expelled or lured from previous forms of livelihood and being incorporated under conditions of exploitation, insecurity and impoverishment into ways of life functional to developmental process".

Perhaps the most pressing threat to the existence of oral literature in Africa is the significant social and cultural change that Africa has undergone and is still undergoing. One of the consequences of this change is the rapid Westernization of the population, which is seriously affecting the situation of oral literature. For example, several Africans are migrating from the rural areas which are homogenous and a natural setting for oral literature as communal art, to the urban areas which are heterogeneous and offer other forms of media entertainment which not only compete with oral literature but dominate it. Since occasions for the performance of oral literature no longer occur in the villages as they did earlier, it follows logically that oral literature as a popular form of entertainment is gradually falling into decline. An obvious solution would be to redouble efforts at recording it especially in areas where there has been no collection at all. Another noticeable and equally important solution is to start exploring possibilities of collecting urban folklore.

There is no doubt that African governments are making half-hearted efforts to salvage their languages, folklore and cultures from extinction and to ensure their survival and growth. However, such efforts are yet to yield the expected dividends. Thus, the bottom line is that African languages, literature and folklore still remain endangered because, having identified and acknowledged the threats posed by globalization, African governments are, in their characteristic style, playing them down. As a result, Africans will, for the foreseeable future, continue to face the dilemma of either encouraging or resisting the process of globalization, unless their governments become more responsive to the cultural needs of their people. However, it is noteworthy that in spite of the threats of globalization to African folklore, there is also a positive aspect (see Sone 2010).

In spite of the challenges listed above, oral literature still permeates some facets of daily life in many parts of Africa. It is true that the occasions for its performance are not as frequent as in the past, but some of its genres, especially folksongs, dirges, modern professional music, topical songs and proverbs as well as annual ritual performances and ceremonies, are still being used in the moral education of the young. Its setting is no longer limited to the village but now extends to the city, an indication that its audience has increased. Its performers are no longer predominantly unlettered, and 
are now influenced by the power that emanates from politics and current events. Finally, it continues to influence the literary works of contemporary African writers both in form and in substance. Although globalization and its 'forces of change' have certainly affected oral literature, they have not destroyed it because oral literature defies extinction. Thus, oral literature transforms itself into new forms when it is threatened but retains its essence. In defense of its existence and adaptability, Heywood (quoted by Sone 2011, p. 48) strongly maintains that "oral literature is not survival but rather a living organism, still growing and developing wherever people live, struggle, hope, despair and die". Thus there is reason to believe that African oral literature is still strong enough to stand up to the challenges of globalization, at least for the time being.

As discussed above, the effects of urbanization and technological advancement have necessitated a change in the direction of research in oral literature. There is the increase of a new audience from a rural audience to a global audience through the aid of modern communication technology, and scholars have to react to the global situation. With films and videos, oral literature can actually be propagated and improved upon. However, the biggest challenge to harnessing the full potential of oral literature is the availability of technological equipment. Nevertheless, the process is on to ensure that oral literature is positioned to remain relevant in an ever-changing world, such that Africa can even export oral literature.

\section{Conclusions}

This paper is undoubtedly a modest intervention in a situation, continentally, which has seen the diminishing role of folklore. In the paper I examined the origin, evolution and emergence of oral literature as an academic discipline in Africa and its place in the humanities. I drew attention to the richness of indigenous knowledge contained in oral literature and demonstrated how the ethical and moral gap in the existing educational system can be filled by the moral precepts embedded in oral literature. I argued that African oral literature has not received the attention it deserves among other disciplines of the humanities in institutions of higher learning in Africa. This is because of the excessive reliance of African tertiary institutions on Western pedagogical models since they emerged from the colonial educational experience. In other words, universities in Africa were introduced by the Western colonial powers in their attempts to fashion educational experience in their image and conceived to serve their purposes. Consequently, a new curriculum and pedagogy must be designed to give pride of place to folklore and oral literature as the best repository of our cultural norms and values, especially in our institutions of higher learning. Starting with the humanities and social sciences, all students in the first and second years should take mandatory courses in these areas to consolidate the decolonisation of our degree programs and make our institutions authentically African. What Africans require as a people, therefore, is not to continue to lament their colonial predicament but to reposition themselves, build up their own resources and prepare for the march towards progress and development within the present context of globalization and taking into cognizance their ecological and environmental peculiarities conditioned by the historical experiences which have endowed them with the democratic philosophy of 'Ubuntu' or collectivism onto which they must cling for survival.

Evidence from this paper is important in the sense that just as the humanities lie at the heart and center of university education worldwide, folklore (oral literature) is the heartbeat of the humanities and should therefore not be neglected. After all, it is the human heart, the human condition and the human nature that are the objects of our study as humanists and folklorists. It is therefore clear that the marginalization of folklore in the humanities must be remedied, because no knowledge-led development strategy can succeed without a solid core of folklore which is the essence of humanistic understanding and humane values. As Chinua Achebe (Achebe [1986] 2008, p. 20) observed, "a grounding in traditional culture was what helped Japan to become an industrial giant because unparalleled inventiveness requires not mere technical flair but archaic energy, the perspective, the temperament of creative myths and symbolism". Franz Fanon submits that no nation of the world will develop properly if it fails to evolve a national consciousness-this national consciousness is 
what Ernest Renan calls the soul. It cannot be overemphasized that oral literature is the soul of African society - that is why we are proud of our oral literature and insist that it should become an all-important subject in all our educational systems at all levels. It is because of these major reasons that we are calling for the concentration of the efforts of each African country in the development of oral literature.

Acknowledgments: I want to wholeheartedly thank the following institutions for providing funds which enabled me to complete this research: The South African National Research Foundation (NRF) for providing Incentive Funding for Rated Researchers-NRF Grant for 2017 and the Directorate of Research and Development at Walter Sisulu University (WSU) for WSU Institutional Research Grant Award for 2017 Top up Funding for NRF Rated Researchers.

Conflicts of Interest: The author declares no conflict of interest.

\section{References}

Abalogu, Uchegbulam N., and Regina Amadi-Tsiwala, eds. 1981. Oral Poetry in Nigeria. Virginia: Virginia University Press.

Abimbola, Wande. 1977. IFA Divination Poetry. New York: NOK Publishers.

Achebe, Chinua. 2008. What has literature got to do with it? In Radical Essays on Nigerian Literatures. Edited by Gabriel G. Darah. Lagos: Malthouse Press Limited. First published 1986.

Alembong, Nol. 1996. Folklore and Identity: Lessons for Cameroon. Epasa Moto: A Bilingual Journal of Language, Letters and Culture 1: 119-24.

ASSAF (Academy of Science of South Africa). 2011. Consensus Study on the State of the Humanities in South Africa: Status, Prospects and Strategies. Pretoria: ASSAF.

Babalola, Adeboye. 1966. The Content and Form of Yoruba Ijala. Oxford: The Clarendon Press.

Bascom, William. 1953. Folklore and Anthropology. Journal of American Folklore 66: 283-90. [CrossRef]

Ben-Amos, Dan. 1974. Folklore in American Society. Bloomington: Folklore Publication Group.

Bleich, David. 2002. Looking for the Human in the Humanities. American Literary History 14: 328-47. [CrossRef]

Brown, Duncan. 1998. Voicing the Text: South African Oral Poetry and Performance. Cape Town: Oxford University Press.

Brown, Duncan, ed. 1999. Oral Literature and Performance in Southern Africa. Oxford: James Currey, Cape Town: David Philip, Athens: Ohio University Press.

Brown, Duncan. 2006. To Speak of This Land: Identity and Belonging in South Africa and Beyond. Pietermaritzburg: University of KwaZulu-Natal Press.

Brown, Duncan. 2014. Reimagining South African Literature. Journal of Southern African Studies 40: 1109-23. [CrossRef]

Brown, Duncan. 2016. Oral Literature in South Africa: 20 Years on. Current Writing: Text and Reception in Southern Africa 28: 108-18. [CrossRef]

Brunvand, Jan. H. 1978. The Study of American Folklore: An Introduction. New York: W.W. Northone and Company, Inc. Bukenya, Austin, Kabira Wanjiku, and Okombo Okoth, eds. 1994. Understanding Oral Literature. Kenya: Nairobi University Press.

Bynum, David E. 1974. Child's legacy Enlarged: Oral literary studies at Harvard since 1856. In Four Generations of Oral Literary Studies at Harvard University Milman Parry Collection 2012. Cambridge: Harvard University.

Ceia, Carlos. 2013. Advanced Research Projects in the Humanities: New Trends on Literature, Languages and Linguistics Studies. Sino-US English Teaching 10: 903-13.

Clark, John Pepper. 1965. Ozidi: A Play. London: OUP.

Clark, John Pepper. 1977. The Ozidi Saga. Ibadan: Ibadan University Press.

Cock, Peter Alan. 1931. History and Izibongo of the Swazi Chiefs. Bantu Studies 5: 181-202. [CrossRef]

Cope, Trevor, ed. 1968. Izibongo: Zulu Praise-Poems. Oxford: Clarendon Press.

Deng, Francis. 1973. The Dinka and Their Songs. Clarendon: OUP.

Dhlomo, Herbert I. E. 1993. Nature and Variety of Tribal Drama. In Foundations in Southern African Oral Literature. Edited by Russell H. Kaschula. Johannesburg: Wits University Press, pp. 187-202. First published 1939.

Dhlomo, Herbert I. E. 1977. Zulu Folk Poetry. English in Africa 4: 43-59. First published 1947-1948.

Dorson, Richard M. 1972. African Folklore. New York: Anchor Books. 
Egudu, Romanus, and Nwoga Donatus. 1971. Poetic Heritage: Igbo Traditional Verse. London: Cambridge University Press.

Eliot, Geraldine. 1951. The Hunter's Cave. London: Routledge.

Finnegan, Ruth. 1970. Oral Literature in Africa. Oxford: The Clarendon Press.

Fonlon, Bernard N. 2010. Challenge of Culture in Africa: From Restoration to Integration. Bamenda: Langaa.

Frye, Northrope. 2007. The Role of the Humanities. Canadian International Youth Letter, 1-3.

Ganyi, Mowang F. 2016. The Liberating Potential of Oral Literature in a Globalized Context. International Journal of Publications and Social Studies 1: 16-30. [CrossRef]

Gardner, David Pierpont. 1986. The Humanities and the Education Reform Movement: What Can Be Done? National Forum 66: 9-11.

Gunner, Liz, ed. 1994. Politics and Performance: Theatre Poetry and Song in Southern Africa. Johannesburg: Wits University Press.

Hicks, Stephen R. 2004. Explaining Postmodernism: Skepticism and Socialism from Rousseau to Foucault. Temple: Scholarly Press.

Hofmeyer, Isabel. 1993. We Spend Our Years as a Tale That Is Told: Oral Historical Narrative in a South African Chiefdom. Johannesburg: Wits University Press, Heinemann: Portsmouth, London: James Currey.

Ighile, Mark O. 2013. Challenges and Prospects of Teaching Oral Literature in Africa. Paper presented at the Nigerian Oral Literature Association Conference (NOLA), Benin, Nigeria, August 7-9.

Ikiddeh, Ime. 1987. Two Decades of African Oral Literature: Towards the Formulation of Critical Standards in the Study of the Literature of Oral Expression. In Critical Theory and African Literature. Edited by Ernest Emmenyonu. Ibadan: Heineman, pp. 132-43.

Jordan, Archibald Campbell. 1973. Towards an African Literature: The Emergence of Literary Form in Xhosa. Berkeley: University of California Press.

Kaschula, Russell H., ed. 1993. Foundations in Southern African Oral Literature. Johannesburg: Wits University Press.

Kaschula, Russell. 2001. African Oral Literature: Functions in Contemporary Society. Claremont: New African Books.

Kaschula, Russell H. 2002. The Bones of the Ancestors Are Shaking: Xhosa Oral Poetry in Context. Cape Town: Juta.

Keil, Charles. 1979. Tiv Song. Chicago: Chicago University Press.

Kimani, Njogu. 2010. Rekindling efficacy: Storytelling for health. In Media and Identity in Africa. Edited by Kimani Njogu and John Middleton. Bloomington: Indiana University Press.

Directed by Dani Kouyaté. 1996. Keita: The Heritage of the Griot. Ouagadougou. Available online: https: / / www.dani-kouyate.com/fr/keita.php (accessed on 15 October 2017).

Kunene, Mazisi. 1961. An Analytical Survey of Zulu Poetry both Traditional and Modern. Unpublished Master's thesis, University of Natal, Durban, South Africa.

Kunene, Daniel P. 1971. Heroic Poetry of the Basotho. Oxford: Clarendon Press.

Lindfors, Bernth. 1977. Forms of Folklore in Africa. Austin: University of Texas Press.

Lord, Albert B. 1960. The Singer of Tales. Cambridge: Harvard University Press.

Makgopa, Mokgale. 2016. Opportunities, Challenges and Dilemmas in the Teaching and Learning of Folklore in South African Schools and Higher Education Institutions: A Case Study. Paper presented at the International Conference of Responsible Research in Education and Management and Its Impact, London, UK, January 13-16.

Mashige, Mashige, and Cleopas Thosago. 2005. Teaching an Eccentric Subject? Why folklore studies is, almost, a non-existent discipline. Journal of Educational Studies 4: 68-77.

Morris, Henry F. 1964. The Heroic Recitations of the Bahima of Ankole. Clarendon: OUP.

Ngugi, wa Thiong'o. 1986. Decolonising the Mind: The Politics of Language in African Literature. Nairobi: EAEP.

Ngugi, wa Thiong'o. 1993. Moving the Centre: The Struggle for Cultural Freedoms. London: James Currey.

Okoh, Nkem. 2012. Of Synergies: Linking Literature, Language and English in Nigeria. Inaugural Lecture; Nsuka: University of Nigeria, pp. 1-93.

Okpewho, Isidore, ed. 1985. The Heritage of African Poetry. Essex: Longman Group Limited.

Okpewho, Isidore, ed. 1990. The Oral Performance in Africa. Ibadan: Spectrum Books.

Okpewho, Isidore. 1992. African Oral Literature: Backgrounds, Character and Continuity. Bloomington and Indianapolis: Indiana University Press.

Okpewho, Isisdore. 2014. Blood and Tides: The Ozidi Saga and Oral Epic Narratology. Rochester: University of Rochester Press. 
Olatunji, Olatunde. 1984. Features of Yoruba Oral Poetry. Ibadan: University Press.

Ongoum, Louis M., and Celestin Tcheho, eds. 1989. Littérature Orale de L'afrique Contemporaine: Approches Théoriques et Pratiques. Yaounde: University of Yaounde.

Opland, Jeff. 1983. Xhosa Oral Poetry: Aspects of a South African Tradition. Johannesburg: Ravan Press.

Opland, Jeff. 1998. Xhosa Poets and Poetry. Cape Town: David Philip Publishers.

Owomoyela, Oyekan. 1989. Proverbs in the Modern Context: Towards a reconciliation of Past and Present. In Littérature Orale de L'afrique Contemporaine: Approches Théoriques et Pratiques. Edited by Louis-Marie Ongoum and Celestine Tcheho. Yaounde: University of Yaounde, pp. 205-14.

p' Bitek, Okot. 1974. The Horn of My Love. London: Heineman.

Parry, Milman. 1971. The Making of Homeric Verse: The Collected Papers of Milman Parry. Edited by Adam Parry. Oxford: Clarendon Press.

Ricard, Alain. 2004. The Languages and Literatures of Africa: The Sounds of Babel. Translated from the French by Naomi Morgan; Oxford: James Currey Limited.

Scheub, Harold. 1996. The Tongue Is Fire: South African Storytellers and Apartheid. Madison: University of Wisconsin Press. Sicherman, Carol. 1998. Revolutionizing the Literature Curriculum in at the University of East Africa: Literature and the Soul of the Nation. Research in African Literatures 29: 129-48.

Sone, Enongene M. 2008. Problems of Oral Literature Research in Swaziland. UNISWA Research Journal 23: 80-92.

Sone, Enongene M. 2009. What Kind of Literature for Ethical Education in Africa? LWATI: A Journal of Contemporary Research 6: 157-65.

Sone, Enongene M. 2010. Digitalization of Cameroon Oral Literature: A New Method in Oral Literature Research. Sarjana 25: 75-86.

Sone, Enongene M. 2011. Swazi Oral Literature Studies Yesterday and Today: The Way forward. The Southern African Journal for Folklore Studies 21: 39-53.

Tala, Kashim. 1999. Orature in Africa. Saskachewan: Saskachewan University Press.

Tala, Kashim I. 2012. Kashimism: Representing Voices. JELLiC: Journal of English Language and Literature and Culture 1: $15-30$

Tala, Kashim I. 2013. Power and Marginality in Cameroonian Orature. Kansas City: Miraclaire.

Thosago, Cleopas Mphela. 1999. Changing Theoretical Trends in the Study of Folklore in South Africa. Available online: http:/ / findarticles.com/p/articles/mi_hb6466/is_2_13/ai_n28756611/pg_5/?tag=content;col1 (accessed on 9 October 2017).

Vail, Leroy, and Landeg White. 1991. Power and the Praise Poem. Charlottesville: University Press of Virginia, London: James Currey.

Vilakazi, Benedict Wallet. 1993. The Conception and Development of Poetry in Zulu. In Foundations in Southern African Oral Literature. Edited by Russell H. Kaschula. Johannesburg: Wits University Press, pp. 55-84. First published 1938.

Vilakazi, Benedict Wallet. 1945. The Oral and Written Literature in Nguni. Unpublished Ph.D. dissertation, University of the Witwatersrand, Johannesburg, South Africa.

Wafula, Lorna. 2012. Teachers' attitudes towards the integrated method of teaching oral literature in secondary schools in Uasin-Gishu County, Kenya. Journal of Emerging Trends in Educational Research and Policy Studies 3: 487-94.

Wasamba, Peter. 2014. Oral Literature Scholarship in Kenya: Achievements, Challenges and Prospects. Paper presented at the International Conference on the Preservation of Ethiopian Cultural and Literary Heritage at Debre Markos University, Debre Markos, Ethiopia, March 1-2.

Wasamba, Peter. 2015. Contemporary Oral Literature Research: A Researcher's Guide. Nairobi: Nairobi University Press. Wilfred, F. 1997. Globalization and Cultures-The Voice. Bulletin of Ecumenical Theology 9: 16-28.

Wilson, William. 1988. Deeper Necessity: Folklore and the Humanities. Journal of American Folklore 101: 156-67. [CrossRef]

Wolf, Marshall. 1995. Globalization and the Social Exclusion: Some Paradoxes. In Social Exclusion Rhetoric: Reality and Responses. Edited by Gerry Rodgers. Geneva: International Institute for Labour Studies.

(C) 2018 by the author. Licensee MDPI, Basel, Switzerland. This article is an open access article distributed under the terms and conditions of the Creative Commons Attribution (CC BY) license (http:/ / creativecommons.org/licenses/by/4.0/). 